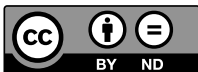

ISSN 2543-506X
Cognitive Science New Media - Education
Vol. 4

$[1 / 2018]$

DOI: http://dx.doi.org/10.12775/CSNME.2018.002

Received: May 30, 2018 / Accepted: a) June 19, 2018; b) July 16, 2018

\title{
Ewa Lubina
}

Warsaw University Of Life Sciences, Warszawa, Poland ewalubina@gmail.com

\section{Academic Teachers after Fifteen Years of E-learning Experience in the Field of Didactics and Organization of Teaching}

\begin{abstract}
The last fifteen years was filled with various experiences aimed at enriching and modernizing educational work. Teachers have used these experiences to gain both knowledge and skills in conducting classes using IT facilities, especially those that are based on Internet communication. They therefore joined the trend that enriches the teaching methodology with more or less formalized e-learning.

The attitudes of academic teachers towards e-learning during these years have changed and reflected various doubts associated with teaching via Internet. Analysis of these changes may be an interesting element of the image of contemporary methodology.
\end{abstract}

Keywords: academic teachers; e-learning experience; didactics

\section{Introduction}

Observers of the modernization of teaching and learning area realize that for various reasons the evolving educational reality has been adopting technical and methodical innovations with great distance and caution. Interestingly, the level of interest and trust did not indicate an upward trend. It would be fair to describe it as unstable. It was related to various 
factors that were revealed in the last 10-15 years. Those have decided that, looking from a distance, we can describe the development stages of Polish academic e-learning by taking the lecturer's optics. It is the lecturer, acting as spiritus movens of this process, who determined the dynamics of its development.

\section{E-learning - imaginations and expectations}

E-learning has raised great hopes as for the development of didactics. Significant changes in teaching were expected to improve this process in many areas (Rossing, Miller, Cecil, Stamper, 2012, 1-26). The abrupt development of the methodology of education was expected (Antonowicz, 2005). The methodology was supposed to get out of the framework of behavioural teaching and evolve in the direction of constructivist models of education (Kąkolewicz-Wach A., Shelest, 2014, 55-56). Great hopes were associated with the motivational function of including online tools in the education process. Young people fascinated by the Internet's communication possibilities were to be a natural target group of e-learning projects. The curiosity of students and their dynamics of searching for knowledge on the Internet were the basis on which e-learning should be based (Sajduk, 2013, 203-212). The opening information resources and their availability stimulated the intellectual development of young Internet users. It is therefore hardly surprising that the academic community was interested in the emerging didactic spaces of e-learning (Dąbrowski, 2013, 203-212).

The intellectual trend popularizing universal access to information has initiated the creation of environments for exchanging experiences, scientific publications and popularizing achievements for free. This tendency, however, met with a slightly colder reception. The sense of intellectual property and the market value of knowledge that stands behind this awareness has slowed down the enthusiasm for sharing information.

Thinking about the universal access to knowledge led to the considerable development of models of non-formal education in the form of massive open online course called MOOC. These courses have mass character (reflected by the unlimited number of participants), they are also widely available and open (commercial, less often non-commercial). MOOC courses are the latest version of e-learning. 
The e-learning potential described here collided with educational reality and encountered constraints of varying degrees of resistance. These constraints could be divided into several groups:

- constraints resulting from the established organizational education model,

- constraints resulting from the habits and methodical conservatism of academic staff,

- constraints that are the result of overgrowth of expectations and imaginations (it will be easy and convenient) of the process participants.

The next stages of the development of academic e-learning were determined by all these constraints, although they appeared at different times and in different proportions. Analysing fifteen years of experience, different stages of e-learning development could be described with the main participants in mind.

\section{Academic teachers in the field of e-learning}

In the description of the development of academic e-learning, it would be worthwhile to adopt a specific perspective, because such perspective determines the way of perceiving the phenomenon. For the needs of this study, the perspective of academic teachers was adopted. They constitute the main development potential of this phenomenon (Babić, Čičin-Šain, Bubaš, 2016, 1103-1108). Of course, they benefit from the technical support of IT specialists and organizational support from the university, however they decide themselves, individually, on the shape and dynamics of inclusion of e-learning in the methodology of teaching. Therefore, it can be concluded that they have the greatest impact on educational practice and thus on the development and popularity of distance teaching.

The perception of e-learning by lecturers is thus a significant criterion for assessing this phenomenon. This method has undergone significant changes over the last fifteen years. Attempts to analyse the situation from the point of view of the lecturer occurred sporadically and were not being generalized. The undertaken research usually referred rather to student experiences (the reason was generally a simplified research methodology). In-depth reflections of academic teachers were elaborated less frequently (Kwiatkowska, 2015, s. 239-249). 
It would be possible to distinguish quite distinct stages of e-learning development determined by the attitudes of its implementers. Then, by adopting the viewpoint of academic teachers as a criterion for division and the characteristics of their activity, three developmental stages could be identified.

\section{The first stage of activity development - the disapproval from the lecturers}

This period can be characterized by the lack of both methodical and technical knowledge in the teaching community. The interest of specialists and enthusiasts resulted in the popularization of experiences acquired in other countries (mainly English-speaking), but they had limited access in Poland. These limitations are mainly a language and methodological barrier, but also a technical barrier - lack of experience in didactic work on online educational platforms (Zając, Zawisza, 2006, 24-28). It was an important disincentive factor. The disapproval of teachers was expressed indirectly. Reluctance in relation to unknown problems was justified not so much by the lack of knowledge as by the conviction that the lack of direct contact makes the education process impossible. This last prejudice is still firmly rooted in the academic teacher community and has its justification).

However, the popularizing activities carried out by a small group of enthusiasts aroused interest in the phenomenon (Barberà E., Gómez-Rey E., Fernández-Navarro, 2016). This group was slowly but surely growing. It created a space for research and implementation in numerous academic communities in Poland. However, it should be noted that these trial implementations were usually initiated spontaneously and in most cases in an informal way. In fact, only a few centres of education officially implemented distance learning, exposing themselves to allegations of violating the law, which in this phase did not sanction education via Internet. The lack of legal grounds and the resistance of the university authorities were not conducive to experiments and popularization of educational practice.

The interested academic teachers, who have access to educational platforms, used them experimentally as support for traditional educa- 
tion, expanding Polish experiences and describing them in the scientific literature (Friesen, 2015).

\section{The second stage of activity development - the legal formalization of e-learning...}

Entering the next development stage was not a breakthrough but a slow process. Universities (mostly non-public) looking for financially beneficial organizational solutions have noticed the potential described in literature by e-learning enthusiasts (savings and free educational platforms) (Hołowiecki, 2014, 185-206). Breaking the barriers of distrust stemmed from the interest in reducing the costs. Academic teachers also noticed the possibilities of facilitating teaching by reducing commuting, making work time more flexible or improving communication (Matysiak, 2009). These arguments were also met with the support of students, especially since they are usually enthusiasts of all novelties and experiments.

Work within the higher education system over the legal validation of e-learning lasted a long time and was discouraging. The solutions finally adopted were unsatisfactory (Skibińska, Kwiatkowska, Majewska, 2014), because by giving permission to provide distance learning, they did not specify the organizational and financial framework, leaving them to be determined by the universities themselves. These, however, got lost in the settlement of hours of lecture and exercise carried out via Internet.

The lecturers plunged into organizational and didactic chaos. The attractiveness of new forms of teaching gave hope for enriching the methodological workshop by introducing new solutions. However, the approach of many universities to formal issues turned out to be rigid and schematic. An example can be the widely used balance of one hour in the classroom with the preparation and implementation of one hour of classes via Internet. Significantly greater time-consuming, labourintensive and conventional methods of settlement by the universities are the main critical points that decided to stop the development of academic e-learning. Practice has shown that e-learning is not only about the inclusion of another didactic aid. There was a need for a systematic change of thinking about teaching and building a new organizational and financial structure. Fleeting interest was replaced by discouragement. 
It is worth mentioning that the business environment coped well with these kinds of problems and created numerous flexible systems for implementing of e-learning. These achievements have been scarcely used in academic structures. There is such experience in different universities, but they are not universal.

\section{The third stage of activity development - simulation of e-learning activities by the universities formally required to implement e-learning to academic didactics}

The divergence characteristic of the second stage of activity development: on the one hand, interest, on the other, discouragement, turned into resistance of academic teachers to various forms of formal pressure. Emphasis on the implementation of the e-learning model for teaching appeared at the moment of legal sanctioning of the e-learning space in higher education and it is exerted on lecturers by the university authorities.

Pressure from the universities themselves is justified by the need to demonstrate the implementation of modern methodological solutions (Skibińska, Kwiatkowska, Majewska, 2014). The e-learning was included in the list of parametric criteria for the evaluation of Polish universities. It seems that social interest and formal obligation have gone by in time. In addition, in most universities there were still no organizational and financial solutions that would support implementation works.

The resistance of the academic community is hidden and reflected in avoiding e-learning tasks or minimalist approach to them. When the principles of settlement of teacher's work are unclear, the teacher naturally creates model of action he or she accepts - a sham action.

Part of the academic community that has been interested in online education has already had various experiences and their analysis. This analysis results in very important observations:

- it confirms the thesis about a strong relationship between the effectiveness of teaching and direct teacher-student contact,

- hopes for making work easier and reducing costs have not been fulfilled,

- the time load of an academic teacher has significantly increased,

- there have been adverse changes in the lecturer-student relation 
ship (a description of these requires in-depth analyses, but it is worth mentioning here).

In the face of these observations, thoughtful lecturers move away from e-learning and return to traditional classes. Significantly, they often give up the already developed models of teaching their subject based on an educational platform. They motivate these decisions in various ways, however, discouragement and withdrawal from the project prevail.

A small part of teachers continues the already implemented methodological solutions, but no further work is being undertaken. They are aware of the work required to prepare them, the effort to implement them and the lack of financial gratification. In assessing the situation, teachers also take into account the moderate interest of students (Kwiatkowska, Majewska, 2015, 24-29).

A very unfavourable situation arose for the development of the methodology of working via Internet. Works in this area must be undertaken by specialist lecturers, although not necessarily by didactic specialists. Obligated by universities and settled on an hourly basis, they have developed the simplest solutions. They meet the criterion of "distance" and "via Internet", but hardly ever meet the quality criterion. Lecturers carry out "mixed" learning: next to traditional classes, they introduce various forms of educational communication via Internet. In practice, they are mainly limited to providing students with self-education materials through online educational platforms. The platforms are also used to collect temporary work and submit grades. In this way, the tool, which is a social educational platform, has been brought to the role of mail. The search for a modern model based on cognitive principles, developing constructivist teaching, was left to the enthusiastic methodologists (Kąkolewicz-Wach, Shelest, 2014, 55-64) (as too cost-intensive).

In terms of methodology, this resulted in a significantly worse effect than in the case of traditional classes (Gómez-Rey, Barbera, FernándezNavarro, 2016 146-163). The most archaic cognitive model is preserved, which is the administration of knowledge, its memory consumption and control of the level of remembering, with the commonly required testing. At the same time, the main value, which is the personal contact with a mentor whose activity and dynamics is motivational and stimulates the learning process, is being removed (Wang, Haggerty, 2009, 571-593). 
The superficial approach of the lecturers themselves reinforces these practices, giving them the appearance of effectiveness (Ordon, Sołtysiak, 2016). The expectation of effectiveness in online teaching provokes wishful thinking (Podlacha, 2015, 113-115). As a consequence of these expectations, a number of activities are undertaken to prove the high-efficiency thesis (Bizon, 2013).

The development of e-learning is determined by the commercialization of education. However, it is commonly known that education has never been and will not be profitable area. In this situation, it is worth paying attention to one more aspect related to the financial background - the certification of skills of teaching via Internet. There have been initiatives to certify academic teachers and lower-level school teachers in the field of e-learning methodologies (Zając, Zawisza, 2006, 24-28). Participants seeking to formalize their skills take trainings grounded in a traditional teaching model and reproduce it in their schools. Formalization of competences limits interest in the development of own methodological workshop. As a consequence, the methodical creativity typical for enthusiasts of the initial stage of development of e-learning disappears.

\section{Development perspectives}

At present, it is difficult to talk about the perspectives of developing elearning. Some academic communities, more involved in technical than didactic development, engage in the dissemination of various possibilities of building an e-learning academic space (e.g. Association of Academic E-learning). However, these are niche activities.

Most of the academic teachers involved in research with the development of teaching methodology face all the above-mentioned constraints and (still) cope with the disapproval of their own universities. The stereotype of incompatibility of social sciences with information and communication technology is still widely spread.

Even a cursory review of the latest publications on the current status of e-learning effectiveness research is not conducive to improving the situation. The overwhelming majority tend to focus on promoting the thesis of very good learning outcomes, leaving aside the multiplicity of problems both on the part of lecturers and on the part of students. These problems, however, should be subjected to a very thorough analysis, be- 
cause, to put it simply, there is no teaching without e-learning. We are no longer facing the question "if?". E-learning has become a reality. Technical development supporting remote education is unstoppable and students also participate in it. Using the traditional concept of e-learning, we embrace the thought of numerous alternative distance teaching models, using smartphones and tablets as well as a wide network along with its social resources (Andrews, Fransman, Meyers, 2016). This inspires to seek not only technical but also methodological solutions. The exploration area is therefore huge.

At this point, leaving aside the question "if", we come to a more relevant question "how?". Currently, the main task of practitioners and researchers is to adapt to the needs of teachers and students all that is available on the Internet. Adaptation means not only creating new technical tools, but also creating various methodological variants enabling their use.

At this point, it is worth devoting a moment to the students' place in the e-learning development process. A closer look at the situation shows a significant phenomenon: students create their own e-learning without waiting for lecturers.

- They create themselves (often beyond the awareness of the lecturer): common mailboxes for circulation of material, discussion groups to support project implementation, organizational and exchange forums. They create materials from lectures or exercises for repetitions or for the absentees (Parker, Chao, 2007, 57-72).

- $\quad$ They are asking the lecturers to provide materials from the classes.

- They use the more or less reliable open sources of information.

- They use MOOC - Massive Open Online Courses (unfortunately, mainly in English).

It seems then that students show redundant and chaotic inventiveness in search of unconventional ways of acquiring knowledge. In this way, they demonstrate their full readiness to learn online, as well as much more methodical creativity than their mentors. 


\section{Conclusion}

In the last fifteen years, academic teachers have come a long way from ignorance to generalized knowledge about student education based on Internet communication. It was not an easy way, because, learning how to teach, they were shaping Polish e-learning from the scratch. At the same time, legal background for the new educational model were formed. Currently, we no longer look at e-learning as an experiment. E-learning gained acceptance, however a bit cool, not enthusiastic. The reasons for this distance have already been exposed, but one of them is worth emphasizing at the end.

E-learning is generally thought of today either as learning from materials sent via e-mail, or learning based on complex educational platforms, that is tools that require complex skills (that is, unfriendly to the ordinary user). These two stereotypes determine the two poles of the vast exploration space. Between them, virtually everyone is able to find a place for their methodological solutions. In fact, every academic teacher more or less consciously undertakes in his or her didactic work numerous activities that fit very well to the scope of e-learning (Turula, 2014, 45-63).

As it has already been said, students themselves initiate informal e-learning projects without noticing that they are actually developing teaching methodology (Klimkiewicz, 2016). It is worth getting involve in this process without the inconvenient idea that we participate in the e-learning.

Among the final conclusions, there should be space for an incentive to recognize technical tools supporting education via Internet. The vast majority of them are based on tools for everyday Internet communication, and this has become an inseparable part of everyday life.

\section{References}

Antonowicz D. (2005), Uniwersytet przyszłości. Wyzwania i modele. Warszawa: Instytut Spraw Publicznych.

Babić S., Čičin-Šain M., Bubaš G. (2016), A Study of Factors Influencing Higher Education Teachers' Intention to Use E-learning in Hybrid Environments Poly- 
technic of Rijeka, Rijeka Croatia: Information \& Communication Technology Electronics \& Microelectronics, Business Department,.

Barberà E., Gómez-Rey E., Fernández-Navarro F. (2016), A cross-national study of teacher's perceptions of online learning success, "Open Learning: The Journal of Open, Distance and e-Learning", Volume 31.

Bizon W. (2013), Efektywność wspomagania zajęć dydaktycznych e-learningiem w akademickim kształceniu ekonomicznym, "E-Mentor", nr 1(43).

Dąbrowski M. (2013), E learning w szkolnictwie wyższym. Warszawa: Kancelaria Sejmu, Studia BAS, 3/2013.

Friesen N. (2015), Report: Defining Blended Learning, NMC Horizon Report: 2015 Higher Education Edition, The New Media Consortium, 2015.

Gómez-Rey P., Barbera E., Fernández-Navarro F. (2016), Measuring teachers and learners' perceptions of the quality of their online learning experience, Journal Distance Education, Issue 2: Growing capacities for sustainable distance e-learning provision.

Hołowiecki M. (2014), Wykorzystanie e-learningu jako formy kształcenia zdalnego na publicznych uczelniach wyższych $w$ Polsce, "Lingua Communitas" 2014, nr 24.

Kąkolewicz-Wach A., Shelest O. (2014), Wyzwolić zaangażowanie, czyli o konstruktywizmie w e-learningu, [in:] E-edukacja w praktyce - wyzwania i bariery, (ed.) M. Dąbrowski, M. Zając, Warszawa: Fundacja Promocji i Akredytacji Kierunków Ekonomicznych.

Kąkolewicz-Wach A., Shelest O. (2014), Wyzwolić zaangażowanie, czyli o konstruktywizmie w e-learningu, [in:] E-edukacja w praktyce - wyzwania i bariery, (ed.) M. Dąbrowski, M. Zając, Warszawa: Fundacja Promocji i Akredytacji Kierunków Ekonomicznych.

Klimkiewicz K. (2016), Budowanie zaangażowania - czyli o wykorzystaniu platformy Moodle w kształtowaniu kompetencji społecznych studentów, “E-mentor" nr 2 (64) / 2016.

Kwiatkowska W., Majewska K. (2015), Doświadczenia studentów w pracy z e-portfolio - raport z badań pilotażowych, "Wychowanie na co dzień" 2015 nr (250).

Kwiatkowska W., Trendy w badaniach nad edukacja na odległość. Przegląd wybranej literatury, [in:] Edukacja a nowe technologie w kulturze, informacji i komunikacji, (ed.) D. Siemieniecka, Toruń: Wyd. Naukowe UMK.

Leja K., Uniwersytet: tradycyjny - przedsiębiorczy - oparty na wiedzy, "Nauka i szkolnictwo" nr 2 (28) 2006. 
Ordon U., Sołtysiak W. (2016), Skuteczność kształcenia akademickiego w formule e-learningu. Wybrane aspekty. "Edukacja - Technika - Informatyka" nr $1 / 15 / 2016$.

Parker K.R., Chao J.T. (2007), Wiki as a teaching tool, "Interdisciplinary Journal of Knowledge and Learning Objects" 2007, No. 3.

Podlacha M. (2015), Miejsce e-learningu we współczesnych metodach nauczania, [in:] Echa ideatorium: z doświadczenia nauczycieli akademickich, uczestników 2. Konferencji Dydaktyki Akademickiej „Ideatorium” na Wydziale Biologii Uniwersytetu Gdańskiego, 2015, (ed.) Mytnik-Eysmont J., Glac W., Majcher J., Gdańsk: Wydział Biologii Uniwersytetu Gdańskiego.

Rossing, J., Miller, W., Cecil, A., Stamper, S. (2012), iLearning: The future of higher education? Student perceptions on learning with mobile tablets, "Journal of the Scholarship of Teaching and Learning", 12(2), 2012.

Sajduk B. (2015), Nowoczesna dydaktyka akademicka, Kraków: Wyższa Szkoła Europejska im. ks. Józefa Tischnera.

Skibińska, M., Kwiatkowska, W., Majewska K. (2014), The Activeness of Learners in the Internet Space, Torun: Wydawnictwo Naukowe UMK.

Strategia rozwoju szkolnictwa wyższego 2010-2020. A. Matysiak (ed.), Warszawa: Wydawnictwo Uniwersytetu Warszawskiego.

The SAGE Handbook of E-learning Research (2016), (ed.) Haythornthwaite C., Andrews R., Fransman J., Meyers E.M., London: Sage.

Turula A. (2014), Kiedy dydaktyka akademicka jest nowoczesna: o potrzebie dywersyfikacji kształcenia na odległość, "Kultura i Polityka" 2014, nr 16.

Wang Y., Haggerty N. (2009), Knowledge transfer in virtual settings: the role of individual virtual competency, "Information Systems Journal" 2009, Vol. 19, No. 5.

Zając M., Zawisza W. (2006), O potrzebie określenia kompetencji nauczycieli podejmujących kształcenie online, "E-mentor" 2006, nr 1(14). 